\title{
An Upper Ordovician (Katian) trilobite fauna from the Lower Ktaoua Formation, Morocco
}

\author{
RICHARD A. FORTEY \& GREGORY D. EDGECOMBE
}

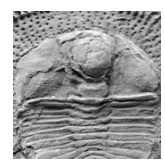

\begin{abstract}
A trilobite faunule from the Lower Ktaoua Formation at Jbel Tijarfaouine in the eastern part of the Anti-Atlas, Morocco, includes well-preserved articulated specimens of the trinucleid Declivolithus titan sp. nov., the cyclopygids Cyclopyge sibilla Šnajdr, 1982, and Heterocyclopyge sp., and the dalmanitid Eudolatites cf. E. galafrea Šnajdr, 1987. All species are either most closely related to or are conspecific with taxa from the middle Katian Bohdalec Formation in the Prague Basin, consistent with a supposed Katian age for the middle part of the Lower Ktaoua Formation and amplifying the close palaeogeographic affinities of Perunica and west Gondwana in the Late Ordovician. However, the Cyclopyge species is much more widespread, consistent with its supposed pelagic life habit, being found as far eastwards as Xinjiang Province, China. - Key words: Morocco, Ordovician, Katian, Declivolithus, Cyclopyge.
\end{abstract}

FORTEY, R.A. \& EDGECOMBE, G.D. 2017. An Upper Ordovician (Katian) trilobite fauna from the Lower Ktaoua Formation, Morocco. Bulletin of Geosciences 92(3), 311-322 (4 figures), Czech Geological Survey, Prague, ISSN 1214-1119. Manuscript received March 13, 2017; accepted in revised form July 18, 2017; published online August 11, 2017; issued September 30, 2017.

Richard A. Fortey \& Gregory D. Edgecombe, Department of Earth Sciences, The Natural History Museum, Cromwell Road, LondonSW7 5BD, UK; r.fortey@nhm.ac.uk,g.edgecombe@nhm.ac.uk

Morocco has yielded many well preserved Cambrian, Ordovician and Devonian trilobites over the last three decades, and the small fauna described in this paper adds further to our knowledge of the later Ordovician. Trilobites have been recognised from the Ktaoua Group in the Anti-Atlas for more than fifty years (see Destombes 1972), and recently some of them have been made available on the open market, but no formal descriptions have been given of the trinucleids and cyclopygids. The names that have been used informally recognise that these trilobites are related to species from the classical successions of Bohemia. For example, the second known species of the spectacular trinucleid Declivolithus Přibyl \& Vaněk, 1967, is described in this paper, the type and only other known species occurring in the Prague Basin. Excellent complete specimens from Morocco supplement knowledge of its distinctive features. Much of the older Czech literature is not available online, so this paper also serves as a summary of some of the previous work on these taxa. Trilobites have proved of particular service in palaeogeographical studies, and the Lower Ktaoua fauna as a whole is relevant to the recognition of the extent of the Ordovician Gondwana palaeocontinent and its fringing terranes.

\section{Field occurrence and palaeoenvironment}

The specimens described herein were collected by Lahcen Ozammu and sons, who prospect for fossils in the region near their farm in Kaïd Rami (El Kaid Errami), Er Rachidia administrative district, in the eastern part of the Anti-Atlas. The trilobites were excavated from the Lower Ktaoua Formation on Jbel Tijarfaouine ( $\left.31^{\circ} 20^{\prime} \mathrm{N}, 04^{\circ} 31^{\prime} \mathrm{W}\right)$, a hill ca. $26 \mathrm{~km}$ west of Rissani (Fig. 1). Quarries at Jbel Tijarfaouine span the massive sandstones of the First Bani Group (late Darriwilian-Sandbian) into the Lower Ktaoua Formation (late Sandian-middle Katian), which is dominated by coarse siliciclastics but with interbedded shales (Van Roy 2006). The trinucleid, dalmanitid and most of the cyclopygid material described herein is preserved as counterpart moulds in grey siltstone from the middle part of the Lower Ktaoua Formation. The same species of cyclopygid is also preserved in relief in a fine-grained sandstone interbedded with the shales.

The material is largely articulated, implying accumulation of exoskeletons on a calm sea floor. However, some of the trinucleids lack the lower lamella and hence are likely to represent undisturbed moults. They were without doubt benthic animals. Therefore, the species described here 


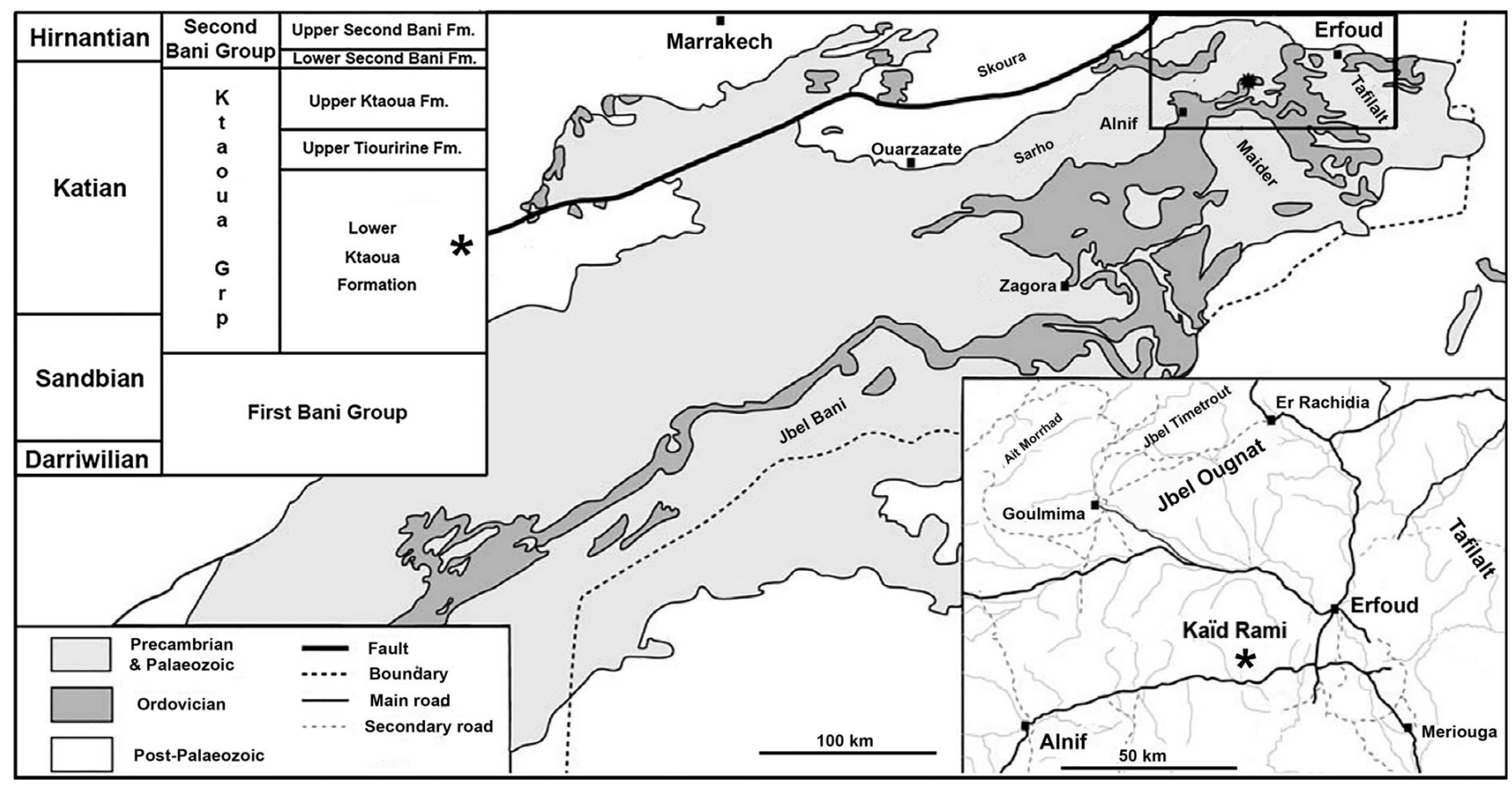

Figure 1. Location of Jbel Tijarfaouine site in the Anti-Atlas (from Nardin 2007) and stratigraphic units in the Upper Ordovician sequence of the Kaïd Rami region (after Van Roy 2006). Asterisks mark locality in map and stratigraphic position.

probably sample a life assemblage. It is of interest that the cyclopygids also show likely moulted exoskeletons since they, too, include articulated examples that lack free cheeks - a particularly robust fused sclerite in this family. If it is correct that these trilobites lived a free swimming life then the implication of these incomplete exoskeletons is that they came down to the sea floor to moult. This was presumably less hazardous than attempting to moult in the open sea. It is also likely that contact with the sedimentary surface facilitated sloughing of the free cheeks. We also note, however, that there are no small holaspides in these assemblages, which implies that earlier growth stages of the species described here may have inhabited a slightly different biotope.

\section{Palaeogeography and age}

We discuss below the details of the affinities of the trilobites in the present fauna. All are compared with taxa in the Bohdalec Formation of the classical Ordovician sequence of the Prague Basin. The presence of Declivolithus is particularly significant. Trinucleids evolved rapidly and were prone to endemicity. Declivolithus titan sp. nov. is the second known species of the genus, and is very similar to the type species, D. alfredi, from the Bohdalec Formation. These are the only localities for this distinctive trilobite. We have identified the cyclopygid with another from the same formation, although this species is probably much more widespread, being a pelagic trilobite that was capable of dispersal around the perimeter of the Ordovician Gondwana palaeocontinent, probably as far as present-day China. Eudolatites species are also closely related to those from the Prague Basin, as Destombes (1972) already recognised. The complete trilobite fauna of the Bohdalec Formation has been reviewed by Vaněk \& Vokáč (1997; also Šnajdr 1987) for comparative purposes. Recent additions to the Lower Ktaoua Formation trilobites (Corbacho \& Kier 2011, Corbacho \& López-Soriano 2013, Corbacho et al. 2014) include Nobiliasaphus, Chattiaspis? and Corrugatagnostus, again with species similar to those from the Prague Basin. Nobiliasaphus is an asaphid closely related to Birmanites, a genus widespread in the Far East (Myanmar and the South China plate). Hence the fauna as a whole is without doubt related to Ordovician Gondwana, and suggests proximity to Bohemia in the Katian. This observation supports continental reconstructions based on faunal evidence such as that of Fatka \& Mergl (2009) which places the "Perunica" microcontinent including the classical Bohemian successions close to the western edge of the Gondwana palaeocontinent in the Upper Ordovician. The most recent treatment of Lower Palaeozoic biogeography by Torsvik \& Cocks (2016) supports this placement. We also conclude that the trilobite fauna of the Lower Ktaoua Formation must be similar (but possibly not identical) in age to the Bohdalec Formation, that is, middle Katian (see Bergström et al. 2009; Fatka et al. 2013, 2015; Gutiérrez-Marco et al. 2017). 


\section{Systematic palaeontology}

Specimens are deposited in The Natural History Museum (London, UK), prefixed NHMUK PI It.

Family Trinucleidae Hawle \& Corda, 1847

Subfamily Trinucleinae Hawle \& Corda, 1847

\section{Genus Declivolithus Přibyl \& Vaněk, 1967}

Type species. - Trinucleus alfredi Želízko, 1906, designated Přibyl \& Vaněk 1967, p. 453.

Discussion. - We follow Hughes et al. (1975) in placing Declivolithus in the subfamily Trinucleinae. The genus has hitherto only included the type species, but a second, closely related species occurs in Morocco (below). Declivolithus is an unusually large trinucleid, with several ranks of pits behind the outer sulcate margin of the fringe (see also Chlupáč 1952 and Vaněk \& Vokáč 1997). It might be considered similar to Trinucleus itself (see Hughes 1971), which has a similarly sulcate cephalic periphery, but $D e-$ clivolithus has a much wider fringe due to many additional pits behind the sulcate zone, and by extending the whole fringe posteriorly. There are about 35-47 rows of pits in Trinucleus fimbriatus according to Hughes (1971) but about 70 in Declivolithus. In the Moroccan species the inner pits are relatively poorly ordered, but they are more organised on the inner margin of the fringe in D. alfredi. Shaw (1995), however, considered Declivolithus as "closely related to Bergamia and possibly Nankinolithus, as well as sharing general cephalic form with Decordinaspis and Reedolithus".

\section{Declivolithus titan sp. nov.} Figure 2A-F

Holotype. - Dorsal shield with associated lower lamella NHMUK PI It29214a, b (Fig. 2B, F).

Paratypes. - More or less complete dorsal exoskeletons NHMUK PI It29211, It29212a, b, It29213a, b, It29215a, b; cephalic shield NHMUK PI It29210.

Type locality. - Middle part of Lower Ktaoua Formation (Katian), Jbel Tijarfaouine.

Etymology. - Titan refers to the Greek giant for this giant among trinucleids.

Diagnosis. - Declivolithus with sulcate cephalic margin that is narrower anteriorly, occupied by two pits; pits inside sulcate margin hardly sorted into radial rows, even at inner margin of fringe.
Description. - The description of the type species by Chlupáč (1952) is thorough, but articulated material from Morocco adds to the knowledge of the morphology of the genus. However, the fringe is flattened out and it is very likely to have been declined in life. This will have implications for comparison with unflattened material, and we choose to emphasise features other than general proportions in the taxonomy. The maximum exoskeleton width at a point close to level with the occipital ring is 1.2-1.3 times the sagittal length, while the width of the fringe (tr.) at this point is approximately equal to that of the adjacent genal lobe in the flattened state. Including the genal spines, the length of the fringe (exsag.) exceeds the sagittal length of the dorsal exoskeleton. The glabella occupies two-thirds cephalic length, and is $30 \%$ longer (sag.) than thorax, which is somewhat longer again than triangular pygidium.

Glabella with inflated circular frontal lobe occupying two-thirds glabellar length, with two pairs of pit-like glabellar furrows behind it adjacent to the axial furrows on the more depressed narrower part of glabella, as is typical for trinucleines. There is also a pit-like furrow adjacent to the axial furrow at the greatest width of the frontal lobe. The occipital furrow is deepened laterally, reflecting a ventral apodeme. Otherwise, the occipital ring is low, slightly wider medially, and there is no evidence of an occipital spine. Genal lobe with an outline approximating a quarter circle, subdivided by a weak ridge extending from the widest part of the anterior glabellar lobe towards the posterolateral corner. Adaxially to the ridge there is a surface sculpture of a fine reticulum; elsewhere, including the frontal lobe of the glabella, there is very fine dense pitting (Fig. 2E). One crushed specimen shows the impression of the hypostome under the frontal lobe of the glabella (Fig. 2D). Impendent in position, it takes up half the glabellar length, and shows the impression of a large subcircular middle body, edged posteriorly by a narrow border of even width. It is like that of raphiophorids and trinucleids in general.

Dorsal surface of fringe with coarse pits. A narrow raised rim surrounds the cephalic perimeter. Only one E arc. With the exception of I 1 inner arcs are not regularly defined and a 'fringe formula' is not calculable. Outer margin of fringe with pits set in sulci between radially disposed ridges. In front of the glabella the ridges are short and only include two pits. Laterally the ridges are longer and a third row of pits is present between them. There is variation between specimens as to when the third row appears. On the smallest example (NHMUK PI It29210) the ridges are relatively prominent. A cast from one perfectly preserved complete external mould (Fig. 2A) shows 68 or 69 pits around the periphery of the fringe. For other specimens, half fringe counts are $35,35,37,38$ respectively, so the range is quite limited. Inside from the organised outer rows the pits are not regularly arranged and discrete arcs cannot be identi- 
fied with assurance. Where they have perhaps fortuitously aligned themselves radially it is possible to identify five (?six) pits spanning the width of the preglabellar area inside the sulcae, rising to seven or eight across the widest part of the fringe. The fringe hugs the edge of the thorax, but beyond that it is prolonged into acutely triangular areas that diverge away from the pygidial margin; in life these were probably inclined. Narrow posterior border is clearly seen in these areas. Lower lamella with well-developed girder that carries finely anastomosing raised ridges on its lower surface (Fig. 2F). Exterior to this, a single E arc comprises the largest tubercles on the ventral surface, matching the outer row on the dorsal surface. The first two I arcs are relatively well organised, but interior to that the pattern of tubercles is irregular. The innermost rows are better seen towards the midline, where a total of six I arcs composed of small tubercles can be identified. The inner margin of the fringe is narrowest and pointed medially, with a similar profile to that of the posterior margin of the pygidium, with which it engaged during enrolment. Short, stout genal spines originating from lower lamella in one available specimen (Fig. 2C, right side) are about same length as the pygidium.

Thorax of usual trinucleid type, subparallel sided, with six similar segments and deep, transverse pleural furrows extending almost to pleural tips. Transverse pygidium varying in width from 2 to 2.6 times as wide as long, with acuminate tip and steeply inclined border, deepest medially. Axis tapers to steeply sloping posterior border, widest medially. Eight or nine pairs of pleural furrows, the most posterior short and hard to discern, extending to narrow raised marginal rim. Ring furrows narrow and complete; the holotype shows half-ring like structures on the anterior three segments.

Discussion. - Declivolithus includes what may be the largest trinucleids known, with some cephalic shields approaching $5 \mathrm{~cm}$ across. The genus has hitherto been known only from the type species, $D$. alfredi, from a type locality in the Upper Ordovician at Rožmitál in the Voltuš Formation of the Czech Republic. The lectotype (selected Přibyl \& Vaněk, 1967) is the original of Želízko (1906, pl. 1, fig. 1; refigured Přibyl \& Vaněk 1967, pl. 1, fig. 1) and is not well-preserved because of slight metamorphism. Better preserved material was given a full and careful description by Chlupáč (1952) under the name Tretaspis novaki. This material was recovered from the "Upper Caradoc" Bohdalec Formation (Katian) of the classical Bohemian Prague
Basin (Barrandian area), and further material from that formation was illustrated photographically by Přibyl \& Vaněk (1969, pls 4, 5; 1972, pl. 5), and much the same material re-illustrated by Vaněk \& Vokáč (1997, pl. 3, figs 1-5) and Shaw (1995, fig. 10.7-13). T. novaki was considered to be a junior subjective synonym of Trinucleus alfredi (e.g. Přibyl \& Vaněk 1967, 1969; Horný \& Bastl 1970, p. 55), which is accepted here with the reservations already noted by Chlupáč (1952, p. 23). Bohdalec material includes examples in full relief, which shows that the anterior lobe of the glabella is much inflated. Further material from the Bohdalec Formation illustrated by Hughes et al. (1975, pl. 3, figs 38, 39), showed details of the lower lamella and the cephalic surface sculpture - a fine reticulum (also Přibyl \& Vaněk 1969, pl. 4, fig. 4) - that Chlupác (1952) had not remarked, but which is also found on our specimens.

All Moroccan examples are flattened to some degree during compaction of the shale in which they are preserved, and the apparently lesser convexity of the glabella compared with $D$. alfredi reflects this. The Lower Ktaoua material is closely comparable to the type species in most features, even in having about 70-80 pits around the perimeter of the fringe, and in the number of rows of pits (insofar as they can be counted) across any given section of the fringe. The structure of the girder is like that of D. alfredi, to the extent of carrying a surface sculpture of fine wavy lines. The principal difference between the Moroccan and Czech species is in the greater organisation of the pit rows forming the inner margin of the fringe in the latter, in which "the first three rows of pits ... are distinctively concentrically arranged and lie in radial sulci” (Chlupáč 1952, p. 20). The same feature is shown by the specimens illustrated by Hughes et al. (1975). Declivolithus titan shows no evidence of sulcae along the flanks of the genal lobes, although the smallest pits of the first three or four rows tend to radial alignment, at least adjacent to the genae, as on the left hand side of the holotype. On other specimens the inner rows of pits are irregularly arranged in the same fashion as the pits further across the fringe. Some specimens of D. alfredi (e.g. Hughes et al. 1975, pl. 3, fig. 39) have longer fringe sulci than any specimen of $D$. titan. The lectotype is also slightly flattened and shows the sulcae extending more than half way across the fringe on the mid-line, whereas they extend hardly one-third across on D. titan. Chlupáč (1952) stated that there are three rows of pits anteriorly within the sulcae (a fourth added posterolaterally in some specimens), whereas the anterior part of the fringe of $D$. titan only includes two pits, and the

Figure 2. Declivolithus titan sp. nov. • A - NHMUK PI It29212b, dorsal shield, latex cast from external mould. • B, F - holotype NHMUK PI It29214a, internal mould of dorsal shield and associated lower lamella; F - detail of raised ridges on lower surface of girder. $\bullet$ C, E - NHMUK PI It29213b, dorsal shield, latex cast from external mould; E - detail of pitting on right cheek. $\bullet$ D - NHMUK PI It 29213a, internal mould, counterpart of C. Scale bars 10 mm except $\mathrm{E}(3 \mathrm{~mm})$ and $\mathrm{F}(2 \mathrm{~mm})$. 

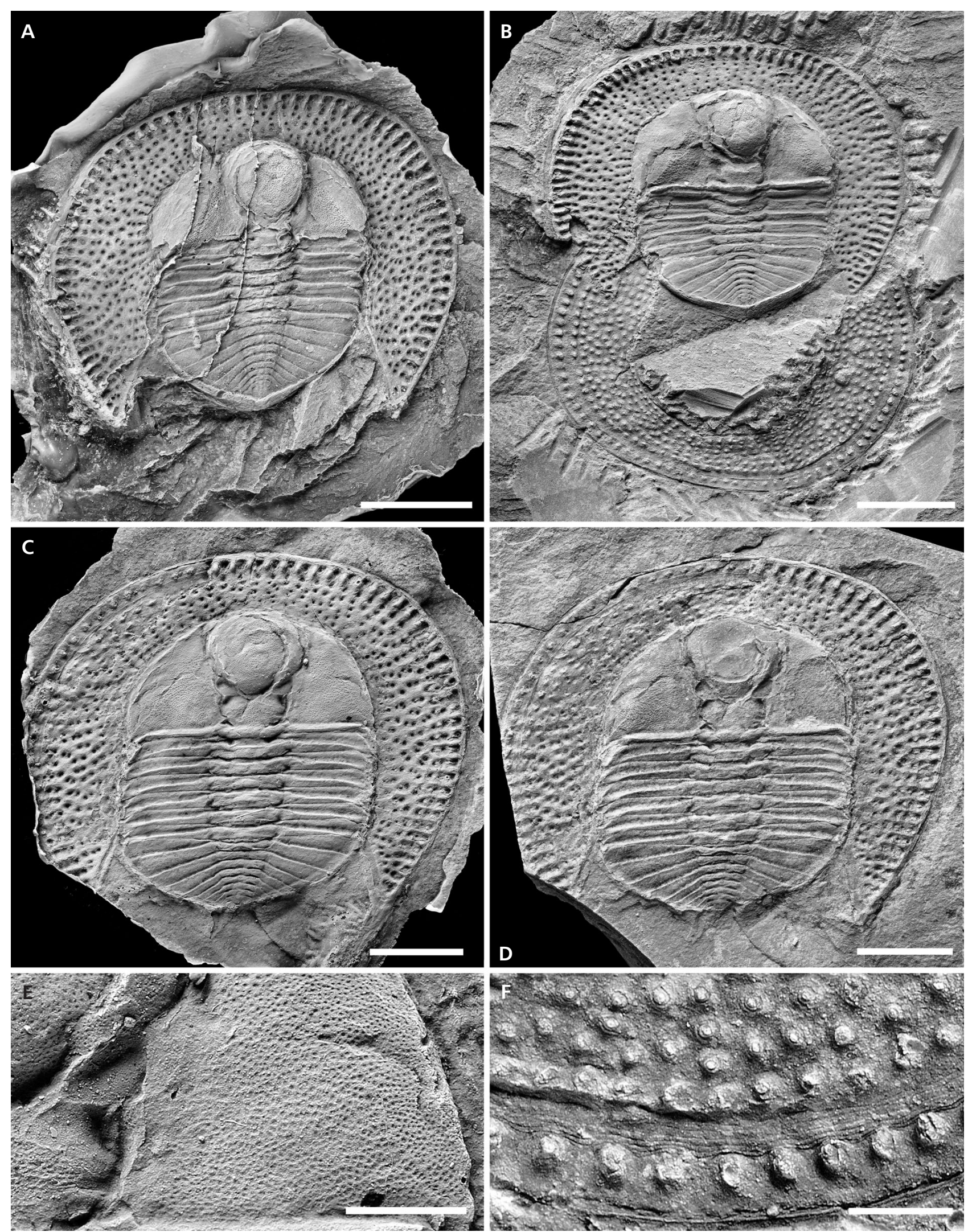
sulcate margin widens towards the broadest part of the cephalon where three pits are usual between the ridges delimiting the sulcae. We note also some that well preserved Bohemian specimens attributed to $D$. alfredi by Přibyl \& Vaněk (1969, pl. 5, figs 4, 9) show the dorsal surface of the fringe carrying a prominent ridge parallel to the cephalic margin inside the $\mathrm{E}$ arc. This is clearly not the case in the Moroccan material, nor in specimens of $D$. alfredi showing good dorsal detail (e.g. Hughes et al. 1975, pl. 3, fig. 39; Přibyl \& Vaněk 1969, pl. 4, fig. 2): in these the girder is not reflected on the dorsal surface. Most of the specimens used by Přibyl \& Vaněk (1969) display the lower lamella. We conclude that the specimens of Přibyl \& Vaněk (1969, pl. 5, figs 4, 9) do not belong within Declivolithus. Apart from this detail, a full of synonymy of $D$. alfred $i$ was given by Vaněk \& Vokáč (1997).

Family Cyclopygidae Raymond, 1925

\section{Genus Cyclopyge Hawle \& Corda, 1847}

Type species. - Egle rediviva Barrande, 1846.

\section{Cyclopyge sibilla Šnajdr, 1982}

Figure 3A-H

1982 Cyclopyge sibilla n. sp.; Šnajdr, p. 229, pl. 1, fig. 2. 1997 Cyclopyge sibilla Šnajdr. - Vaněk \& Vokáč, p. 27, pl. 2, figs 1-11.

2011 Cyclopyge sp. - Corbacho \& Kier, pl. 2, fig. 3.

Material. - More or less complete dorsal exoskeletons NHMUK PI It29200-29204, It29206a, b, It29207a, b, It29208a, b.

Description. - Most of our material is flattened, but one dorsal exoskeleton lacking free cheeks retains full relief (Fig. 3D-F), although it is preserved in arenaceous matrix that fails to preserve external details. Nonetheless this specimen proves that the transverse convexity across the glabella is greater than it is across the posterior part of the thorax and the pygidium, the latter sloping gently downwards posteriorly. The eyes would have been subtended at the lateral margin in such a way that they hung below the rest of the dorsal exoskeleton (Han \& Zhang 1985). The deeply parabolic glabellar outline is preserved during flattening that affects the specimens preserved in shale, appar- ently without altering the proportions. The length of the cranidium (sag.) is very close to its maximum width (tr.) close to its posterior margin, and between 0.45 and 0.48 of the total exoskeletal length. The single pair of commashaped glabellar furrows is more readily apparent in the relief material than on flattened examples, where they can be nearly obliterated. They constitute a reliable character for distinguishing Cyclopyge from other cyclopygids. The posterior border is reduced to a triangular area widening laterally, while the palpebral lobe is a narrow selvage running around the edge of the cranidium to at least two thirds its length. The eyes are holochroal, with hexagonal lenses in gently spiralling files with about 24 lenses per file. The free cheeks are fused as a single piece, and one specimen shows lenses continuing to the mid-line (Fig. 3H, arrow), although the height of the eyes must have been narrower there; hence the eyes were probably fused anteriorly. The specimen figured in Fig. $3 \mathrm{G}$ shows much of the visual surfaces, while on the left it has broken to display what would have been the ventrally facing part of the left-hand eye, with the very wide doublure uniting the cheeks carrying strongly developed, widely spaced terrace ridges. The cheeks + doublure of this specimen have been skewed slightly to the right so that the maximum width of the doublure is not in line with the sagittal line of the rest of the exoskeleton. Hypostome not discovered.

Thorax with six segments, posterior three segments with notably truncate tips. Thorax expands in width slightly backwards as the pleurae become longer at the same time as the axis tapers. Facets on the first three segments are strongest, with the articulation of the anterior segment close to the axial furrow. Pleural furrow originally rather deep and extending close to the pleural tips, but may be obscured by flattening. Outline of axis rather zig-zag; all rings of similar width (sag.). Two specimens show a median deflexion and shallowing of the ring furrows on posterior segments (e.g. Fig. 3A, B). While this may have been thought of as a preservational feature, it has also been shown on Cyclopyge from China (Zhou et al. 1994, fig. 4e) and may be the consequence of flattening a median inflation of the axial rings.

Pygidium close to half (sag.) length of cephalon, and its length between 0.47 and 0.53 maximum transverse width at anterior margin. Narrow border 0.15 or less length of pygidium and widening very slightly laterally; it is probably coincident with the doublure. Axis $0.35-0.4$ length of pygidium and wider than long, with broadly parabolic

Figure 3. A-H - Cyclopyge sibilla Šnajdr, 1982. • A - NHMUK PI It29202, complete specimen. • B - NHMUK PI It29403, axial shield. • C - NHMUK PI It 29206, complete specimen with displaced cephalon. • D-F - NHMUK PI It29204a, dorsal (D), lateral (E) and dorsal anterolateral (F) views of axial shield, internal mould. • G - NHM UK PI It20207, complete specimen with part of glabella removed to expose ventral side. • H - NHMUK PI It29200, internal moulds of two axial shields and visual surface (indicated by arrow at left). $\bullet$ I-J - Heterocylopyge sp. NHMUK PI It29205, partial thorax and pygidium, dorsal (I) and lateral (J) views of internal mould. All scale bars $3 \mathrm{~mm}$. 

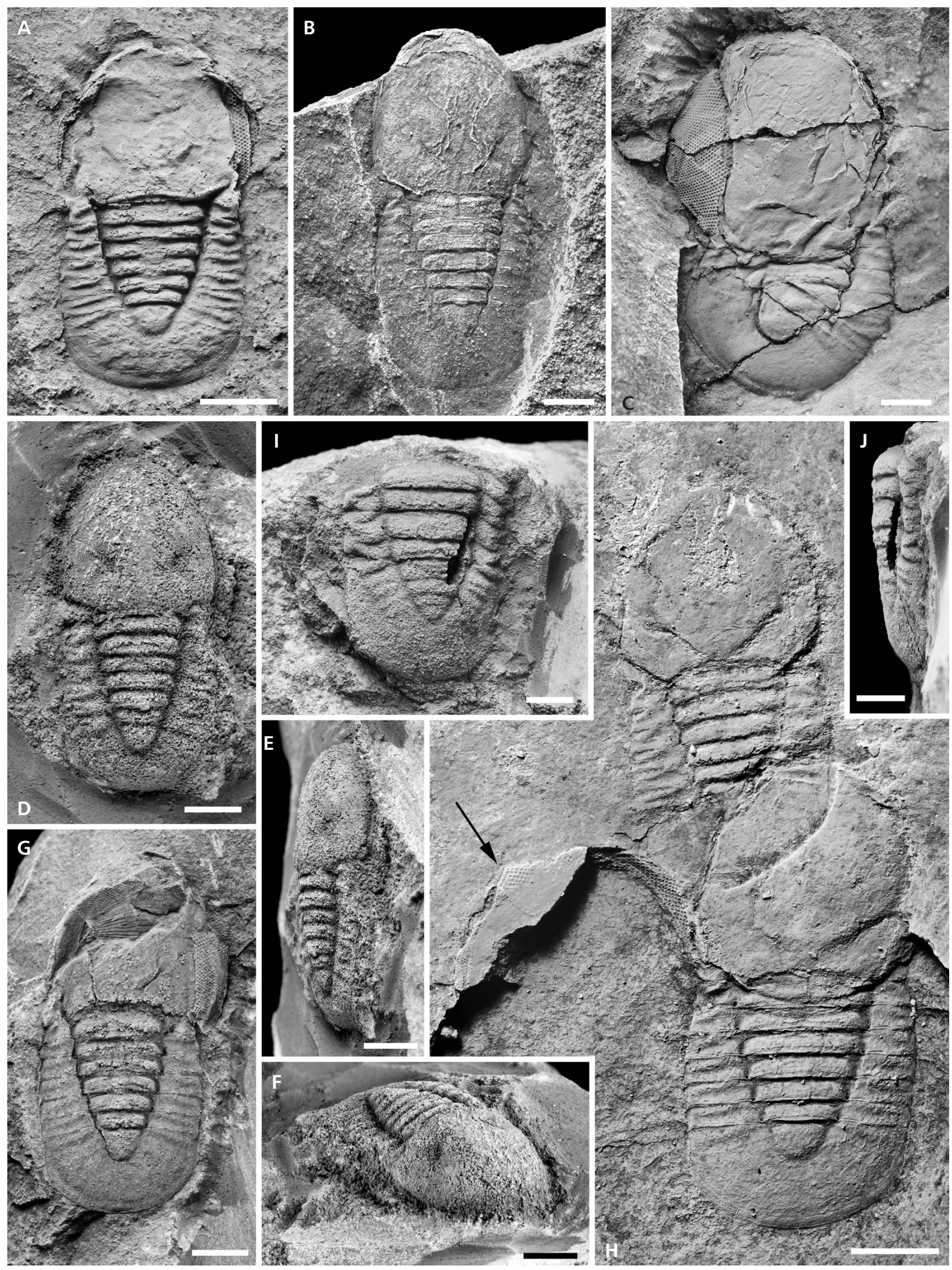
outline and no defined axial ring. Apart from the anterior half rib the pleural fields are without obvious pleural furrows apart from a faint furrow in NHMUK PI It20207 (Fig. 3G). No sculptural details preserved on the exoskeleton.

Discussion. - The Moroccan species belongs to a group of Cyclopyge species in which there are no well-defined axial rings on the mature pygidium. Many species, particularly from the earlier Ordovician, have one or two well-defined rings comparable with those on the thorax. The type species Cyclopyge rediviva shows two pairs of pygidial pleural furrows on well-preserved specimens in relief (Marek 1961). This feature is not clear on the flattened lectotype (see Horný \& Bastl 1970) but it could be assumed that this is because of the more compressed preservation. No such furrows are present on our specimen in full relief. Marek (1961) also noted that the length (sag.) of the pygidium of C. rediviva is $75 \%$ of its width. Measurements from other figured specimens and from a few pygidia in the Natural History Museum, London (NHMUK PI It59431), suggest a greater range (60-75\%) but always more than half, the ratio in our specimens. The eyes of $C$. rediviva are stated by Marek (1961) to be separate at the anterior cephalic margin. Transitory pygidia of all Cyclopyge species retain one or two well-defined segments. It seems possible that in the type species this immature condition has been carried forward heterochronically into the holaspis. The type specimen of C. sibilla (Šnajdr, 1982) from the Bohdalec Formation is small and with two segments, and is probably a transitory pygidium, and therefore not diagnostic. However, Vaněk \& Vokáč (1997) recognised mature Cyclopyge sclerites from the Bohdalec Formation, and applied Śnajdr's name to them, on the assumption that there is only one Cyclopyge species present in that formation. These cranidia and pygidia are indistinguishable from the new and more complete material from the Lower Ktaoua Formation, notably having wide pygidia that lack or have at most one faint pygidial pleural furrow; given the other similarities between the Bohdalec fauna and Moroccan ones it would be difficult to use any other species name. We presume also that a cranidium figured as Cyclopyge sp. by Corbacho \& Kier (2011) from the Lower Ktaoua Formation again represents the same species. Given the immaturity of the type specimen of $C$. sibilla a measure of uncertainty inevitably remains.

This nomenclatural problem is compounded further because another, closely similar species has been described by Zhou et al. (1994) from the Nemagraptus gracilis Biozone of northeastern Tarim, China, as Cyclopyge cf. recurva Lu, 1962. Those authors listed and discussed a number of other similar Asian species, none of them adequately described. Interestingly, Zhou et al. (1994, fig. $4 \mathrm{~g}$ ) figured an articulated specimen showing the same median thoracic inflated areas as shown in Fig. 3A, B herein. They also figured a meraspis pygidium (1994, fig. 4i) displaying the two unreleased segments shown on the type of C. sibilla. Zhou et al. (1994; also Zhou \& Dean 1986) were not able positively to identify such material with $C$. recurva Lu, 1962, because of the then inadequate knowledge of its type material from the Pagoda Limestone (see also Lu 1975). They state that " $C$. cf. recurva is characterised by the anteriorly narrower eyes" which is also the case on our Moroccan species. Given that Cyclopyge was a pelagic trilobite (e.g. Fortey 1985) there seems no reason why a single species should not have dispersed along deeper palaeoenvironments surrounding the periphery of the Ordovician Gondwana palaeocontinent.

We consider it likely that the species described here as C. sibilla is conspecific with $C$. cf. recurva of Zhou et al. (1994) from Tarim. The true C. recurva from the Pagoda Limestone of the Yangtse Block has recently been fully redescribed by Zhou et al. (2016). This material displays a cephalon like that of the Moroccan species; however, the pygidium has a wider border and pleural fields with clear segments defined by thin, raised ridges. Fortey (1997) identified material from the Thai equivalent of the Pagoda Limestone - the Pa Kae Formation - with C. recurva, but this material was reassigned by Zhou et al. (2016) to C. subcylindrica Chen (in Li et al. 1975). If it is correct that the species described here under the name $C$. sibilla is globally widespread it is quite possible that another name will prove to have priority, including one of the species of Koroleva (1967) from Kazakhstan listed in Zhou et al. (1994), which have historical priority. A global revision of Cyclopyge is needed to clarify the taxonomy.

Occurrence. - Middle part of Lower Ktaoua Formation (Katian), Jbel Tijarfaouine.

\section{Genus Heterocyclopyge Marek, 1961}

Type species. - Cyclopyge pachycephala Hawle and Corda, 1847.

Discussion. - Although Heterocyclopyge has been considered as a subgenus of Microparia (e.g. Zhou et al. 1994), species assigned to it share a deep, subquadrate pygidial profile and relatively well-defined, acutely triangular pygidial axis with three axial rings, suggesting that they comprise a clade distinct from relatively effaced Microparia. We follow Marek (1961) in treating Heterocyclopyge as a separate genus.

\section{Heterocylopyge sp.}

Figure 3I-J

Material. - A single incomplete thorax and pygidium, NHMUK PI It29205. 
Discussion. - A single incomplete specimen without cephalic parts cannot be precisely determined. It is, however, well preserved in relief and possesses four posterior thoracic segments. The thoracic pleurae are very short (tr.), with deep pleural furrows not extending to the truncate tips of the pleurae. The posterior margin of the posterior thoracic pleura curves towards the hammer-like tip of the pleura. It is at once distinguished from Cyclopyge in its subquadrate pygidial outline, and its well-defined, tapering triangular pygidial axis with three axial rings that diminish in width (sag.) posteriorly to a terminal piece that is approximately an equilateral triangle. The axis occupies just over $50 \%$ sagittal length of pygidium. Two pleural pygidial segments are defined, showing both pleural and interpleural furrows, but they terminate rather abruptly far from the pygidial margin. In profile, the pygidium is convex behind the axis. The deeply curved profile of the pygidium is like that of the type species of Heterocyclopyge from the lower Katian (see Gutiérrez-Marco et al. 2017) Vinice Formation of Bohemia (Marek 1961), but that species has a clearly defined pygidial border and a blunt tip to the pygidial axis. H. shelvensis (Whittard 1961, pl. 24, figs 3, 4) from the Katian(?) Stapeley Volcanic Formation, UK, closely resembles the type species, and differs from our new material in similar features. The somewhat older species H. nigra Horbinger and Vaněk 1985 from the Dobrotivá Formation of the Prague Basin is readily distinguished from the Moroccan form in lacking pygidial pleural furrows. Heterocyclopyge abunda (Zhou et al. 1994) from the Nemagraptus gracilis to Climacograptus bicornis biozones (Sandbian) of the Charchaq Group, China, is known from abundant material compared with other described species. This differs consistently from the Moroccan species in having the terminal piece of the pygidial axis relatively effaced, while the axis as a whole extends to much more than $50 \%$ pygidial length; pygidial pleural furrows are much longer. Interestingly, Zhou et al. (1994, fig. 5h) illustrated a specimen with a 'hooked' posterior thoracic pleura like that on our specimen. It seems likely that we have an undescribed species from Morocco, but the material to hand is not sufficient to name it formally.

Family Dalmanitidae Vogdes, 1890

\section{Genus Eudolatites Delo, 1935}

\section{Type species. - Dalmanites angelini Barrande, 1852.}

Remarks. - The genus Eudolatites has been divided into four subgenera by Destombes (1972) and Šnajdr (1987). The distinctions between E. (Eudolatites) Delo, E. (Banilatites) Destombes, E. (Deloites) Destombes, and E. (Destombesites) Šnajdr are in the relative expression
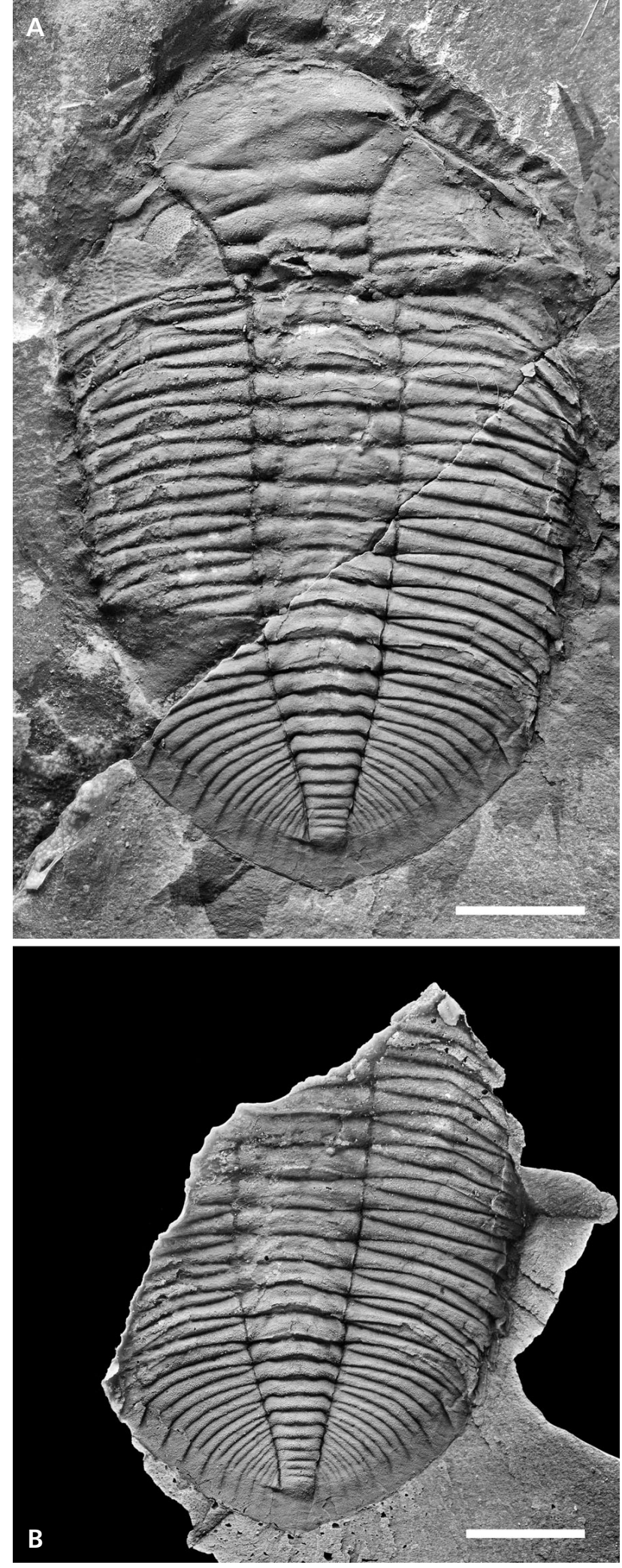

Figure 4. Eudolatites cf. E. galafrea Šnajdr, 1987. • A - NHMUK PI It29209a, dorsal exoskeleton, internal mould. • B - NHMUK PI It29209b, latex cast from external mould. Scale bars $5 \mathrm{~mm}$. 
and width of the pygidial border and the extent to which interpleural furrows pass on to it. A species discovered in the present fauna is very similar to the type species of E. (Eudolatites) from the Bohdalec Formation of Bohemia, having a weakly defined border on to which the backward-curving interpleural furrows pass and just fail to reach the margin. However, several similar-looking species were named by Šnajdr (1987) as the basis for his subgenus Destombesites, including one also from the Bohdalec Formation. His assertion in diagnosing Destombesites that "the rhachis reaches the posterior pygidial margin" is puzzling, as it stops at the border. Furthermore, the transverse width of the axis is stated to be " $0.2-0.3$ pygidial width" into which range a Moroccan species (below) falls. What may be the same Moroccan species was described by Destombes (1972) in the subgenus Eudolatites (Eudolatites), and we see no reason to question that here. It is likely that the subdivisions of Eudolatites require further scrutiny, but our sparse material is not a good basis on which to do that, and Eudolatites is used in the wider sense here.

\section{Eudolatites cf. E. galafrea Šnajdr, 1987}

Figure 4A, B

?1972 Eudolatites (Eudolatites) sp. - Destombes, p. 43-45, pl. 5 , figs $1-7$, text-fig. 3 .

Material. - Slightly crushed dorsal exoskeleton NHMUK PI It29209a, b.

Remarks. - The single specimen available is flattened, and the cephalon may be somewhat foreshortened. The free cheeks have been detached and pushed backwards so that part of the visual surface is visible on the left. Crushing of the frontal glabellar lobe against the doublure may have accentuated the appearance of a shorter, more transverse frontal lobe. There is also a question about the original position of the eye, because the right-hand side of our specimen apparently shows the palpebral lobe in a relatively anterior position. The Lower Ktaoua specimen is best considered in relation to descriptions of other taxa. It belongs within a group centred on the Bohemian type species from the Bohdalec Formation (Barrande 1852, pl. 23, figs 21-27; Přibyl \& Vaněk 1972, pl. 2, fig. 2, pl. 3, fig. 1, pl. 5, figs 3, 4; Vaněk \& Vokáč 1997, pl. 7, fig. 1.2). This is generally similar to our species in having long pygidial interpleural furrows that curve back on to the border, but Barrande's (1852) and Přibyl \& Vaněk's (1972) illustrations prove that the pygidia of the Bohemian species are relatively longer, with width/length ratios about two-thirds rather than half as in the Moroccan specimen. Commensurate with this is the greater number of segments in the type species: 15 axial rings compared with 11 in the Moroccan example, and with 12 or 13 pygidial pleurae as opposed to eight (faint ninth) in our specimen. Destombes (1972) described a species from the same formation in Morocco that shares the same wide pygidium with relatively few segments and narrow pygidial borders. This species was left in open nomenclature by Destombes (1972), but it may represent the same species as ours, although better-preserved cephalic shields are available in his collection. Pygidia of E. angelini come to a point posteriorly, as does our specimen, but this is not clear on Destombes' specimens; however his pl. 5, fig. 6 has exfoliated along the doublure, and there appears to be a measure of distortion in his other two pygidia. Šnajdr (1987) named Eudolatites (Destombesites) promura from the Letná Formation of Bohemia on the basis of a pygidium that shows a similar number of segments to our example, but a width/length ratio similar to that of E. angelini. The Letná species also lacks any indication of a pygidial border. The closest match is another species from the Bohdalec Formation, E. galafrea Šnajdr 1987. Its original description was perfunctory, but additional information on it was provided by Vaněk \& Vokáč (1997). The cephalic differences they cite from E. angelini are difficult to assess on our material because of its imperfections, but the proportions of the pygidium, concavity of the pygidial border, and number of axial rings and pleural segments are similar. Hence we compare our material with that species, while recognising that the whole group around E. angelini would benefit from comparative revision.

Occurrence. - Middle part of Lower Ktaoua Formation (Katian), Jbel Tijarfaouine.

\section{Conclusions}

A small trilobite fauna is described from the Lower Ktaoua Formation at Jbel Tijarfaouine in the eastern part of the Anti-Atlas, Morocco, and includes well preserved articulated material of trinucleids and cyclopygids and incomplete Eudolatites. The species are strikingly similar to those from the middle Katian Bohdalec Formation of the Prague Basin, reinforcing the palaeogeographic connections between Perunica and west Gondwana in the late Ordovician, and suggesting a similar age. Declivolithus titan sp. nov. is the second known species of a distinctive benthic genus that is confined to this region, and one of the largest trinucleids. A pelagic Cyclopyge species identified as C. sibilla Šnajdr, 1982, can be compared with species from much more dispersed localities, including the Tarim Basin, China. Axial shields of Cyclopyge lacking cheeks are common in the Lower Ktaoua Formation, suggesting that these trilobites came down to the sea floor when they were ready to moult. 


\section{Acknowledgement}

We thank Petr Budil and Robert Owens for their helpful reviews of the manuscript. GDE thanks the Ozammu family for their hospitality.

\section{References}

BARRANDE, J. 1846. Notice préliminaire sur le systême Silurien et les trilobites de Bohême. 40 pp. C.L. Hirschfeld, Leipzig. DOI 10.5962/bhl.title.9142

BarRande, J. 1852. Systême Silurien du centre de la Bohême. lère partie. Recherches Paléontologiques. Vol. 1. Trilobites. 935 pp. Prague \& Paris.

Bergström, S.M., Chen, X., Gutiérrez-Marco, J.C. \& Dronov, A. 2009. The new chronostratigraphic classification of the Ordovician System and its relations to major regional series and stages and to $\delta^{13} \mathrm{C}$ chemostratigraphy. Lethaia 42, 97-107. DOI 10.1111/j.1502-3931.2008.00136.x

Chlupáč, I. 1952. A new species of the genus Tretaspis McCoy (Trilobita) from the Ordovician of Bohemia. Sborník Ústředního ústavu geologického 19, 200-207.

Corbacho, J. \& Kier, C. 2011. Trilobites of a new outcrop of Upper Ordovician in Jbel Tijarfaïouine, El Kaid Errami (Morocco), with first mention of genus Corrugagnostus. Scripta Musei Geologici Seminarii Barcinonsis, Series palaentológica 10, 2-12.

Corbacho, J. \& López-Soriano, F.J. 2013. Chattiaspis? budili: a new Dalmanitidae species from Morocco; Upper Ordovician (Lower Katian). Batalleria 19, 6-11.

Corbacho, J., Morrison, S. \& Addi, A.A. 2014. Dionide carlottae: Una nueva especie de Dionididae (Trilobita) del Ordovícico superior de Marruecos. Batalleria 21, 13-21.

Delo, D.M. 1935. A revision of the phacopid trilobites. Journal of Paleontology 9, 402-420.

Destombes, J. 1972. Les trilobites de sous-ordre des Phacopina de l'Ordovicien de l'Anti Atlas (Maroc). Notes et Mémoires du Service des Mines et de la Carte Géologique du Maroc 240, $1-111$.

FatKa, O. \& Mergl, M. 2009. The 'microcontinent' Perunica: status and story 15 years after conception. Geological Society of London, Special Publications 325, 65-101. DOI 10.1144/SP325.4

FAtKA, O. BudIL, P. \& DAvid, M. 2015. Digestive structures in Ordovician trilobites Colpocoryphe and Flexicalymene from the Barrandian area of Czech Republic. Estonian Journal of Earth Sciences 64, 255-266. DOI 10.3176/earth.2015.32

FAtKa, O., Lerosey-Aubril, R., Budil, P. \& RAK, Š. 2013. Fossilised guts in trilobites from the Upper Ordovician Letná Formation (Prague Basin, Czech Republic). Bulletin of Geosciences 88, 95-104. DOI 10.3140/bull.geosci.1329

ForTEY, R.A. 1985. Pelagic trilobites as an example of deducing the life habits of extinct arthropods. Transactions of the Royal Society of Edinburgh: Earth Sciences 76, 219-30. DOI 10.1017/S0263593300010452
FORTEY, R.A. 1997. Late Ordovician trilobites from southern Thailand. Palaeontology 40, 397-450.

Gutiérrez-Marco, J.C., Sa, A.A., García-Bellido, D.C. \& RÁBANO, I. 2017. The Bohemo-Iberian regional chronostratigraphical scale for the Ordovician System and palaeontological correlations within South Gondwana. Lethaia 50, 258-295. DOI 10.1111/let.12197

HAN, N.R. \& Zhang, Y. 1985. Holochroal eyes of Cyclopyge. Geology Review 29, 390-395.

Hawle, I. \& CoRdA, A.J.C. 1847. Prodrom einer Monographie der Bohmischen Trilobiten. Abhandlungen der königlischen Böhmischen Gesellschaft der Wissenschaften. Folge 5, 1-176.

HoRBINGER, F. \&VANĚK, J. 1985. New cyclopygid trilobites from the Ordovician of Bohemia. Časopis pro mineralogii a geologii 30, 59-64.

HoRnÝ, R. \& BASTL, F. 1970. Type specimens of fossils in the National Museum Prague: Trilobita. 354 pp. National Museum, Praha.

HugHES, C.P. 1971. The Ordovician trilobite faunas of the Builth Llandrindod Inlier, central Wales. Part 2. Bulletin of the British Museum (Natural History) Geology 20, 115-182.

Hughes, C.P., Ingham, J.K. \& AdDison, R. 1975. The morphology, classification and evolution of the Trinucleidae (Trilobita). Philosophical Transactions of the Royal Society of London, Series B 272, 537-607. DOI 10.1098/rstb.1975.0100

Koroleva, M.N. 1967. Trilobites of the Family Cyclopygidae in Kazakhstan. Paleontologicheskij Zhurnal 1967, 79-91.

Li, Y.X., Song, L.S., Zhou, Z.Q. \& YANG, X.Y. 1975. Early Palaeozoic stratigraphy of the western part of Tapa Mountain. 232 pp. Earth Sciences Publishing House, Beijing. [in Chinese]

Lu, Y.H. 1962. Middle Ordovician index trilobites, 52-53. In WANG, Yu (ed.) Handbook of the Index fossils of the Yangtze region. Science Press, Beijing.

Lu, Y.H. 1975. Ordovician trilobite faunas of central and southwestern China. Palaeontology Sinica 152, 1-463.

MareK, L. 1961. The trilobite family Cyclopygidae Raymond in the Ordovician of Bohemia. Rozpravy Ústředního ústavu geologického 28, 1-84.

NARDIN, E. 2007. New occurrence of the Ordovician eocrinoid Cardiocystites: Palaeogeographical and palaeoecological implications. Acta Palaeontologica Polonica 52, 17-26.

Pर̌IBYL, A. \& VANĚK, J. 1967. Declivolithus gen. n. eine neue Trilobiten-Gattung aus dem bohmischen Mittel Ordovizium. Časopis pro mineralogii a geologii 12, 453-456.

PřIBYL, A. \& VANĚK, J. 1969. Trilobites of the family Trinucleidae Hawle \& Corda, 1847, from the Ordovician of Bohemia. Sborník Geologických Věd, Paleontologie 11, 85-137.

PŘIBYL, A. \& VANĚK, J. 1972. O vzájemných vztazích trilobitů z rožmitálského a barrandienského ordoviku. Vlastivědný Sborník Podbrdska 6, 7-27.

RAYMOND, P.E. 1925. Some trilobites of the lower Middle Ordovician of eastern North America. Bulletin of the Museum of Comparative Zoology at Harvard College 67, 1-180.

SHAw, F.C. 1995. Ordovician Trinucleid Trilobites of the Prague Basin, Czech Republic. Journal of Paleontology Memoir 69, 3, 1-23. 
ŠNAJDR, M. 1982. New trilobites from the Bohdalec Formation (Berounian) in the Barrandian. Věstník Ústředního ústavu geologického 57, 227-230.

ŠNAJDR, M. 1987. New Bohemian Ordovician Dalmanitidae and Calmoniidae (Trilobita). Věstník Ústředního ústavu geologického 62, 271-277.

TORSVIK, T.H. \& Cocks, L.R.M. 2016. Earth history and palaeogeography. 310 pp. Cambridge University Press, Cambridge.

VANĚK, J. \& VOKÁČ, V. 1997. Trilobites of the Bohdalec Formation (Upper Berounian, Prague Basin, Czech Republic). Palaeontologia Bohemiae 3, 20-50.

VAN Roy, P. 2006. Non-trilobite arthropods from the Ordovician of Morocco. 230 pp. Ph.D. thesis, Universiteit Gent, Gent, Belgium.

Vogdes, A.W. 1890. A bibliography of Paleozoic Crustacea from 1698 to 1889, including a list of North American species and a systematic arrangement of genera. U.S. Geological Survey Bulletin 63, 1-177.
WhitTARD, W.F. 1961 The Ordovician trilobites of the Shelve Inlier, West Shropshire part 5. Palaeontographical Society Monographs 113, 163-196.

ŽELízKo, J.V. 1906. Geologicko-paleontologické poměry nejbližšího okolí Rožmitálu. Rozpravy České akademie císaře Františka Josefa pro vědy, slovesnost a umění, Tř́da II, 15, $1-27$.

Zhou, Z.Q., Zhou, Z.Y. \& XIANG, L.W. 2016. Trilobite fauna from the Ordovician Pagoda Formation of central and western Yangtze Block, China CIP. 360 pp. China Publishing House, Beijing.

Zhou, Z.Y. \& DeAn, W.T. 1986. Ordovician trilobites from Chedao, Gansu Province, North-west China. Palaeontology 29, 743-786.

Zhou, Z.Y., McNamara, K.J., Yuan, W.W. \& Zhang, T.R. 1994. Cyclopygid trilobites from the Ordovician of Northeastern Tarim, Xinjiang, Northwest China. Records of the Western Australian Museum 16, 593-622. 